There is evidence to suggest that peptic ulceration and cardiovascular disease occur together more commonly than would be expected by chance. Abdominal aortic aneurysm has been linked with peptic ulcer disease (Jones et al., 1970; British Medical fournal, 1971), and both Allan and Dawson (1968) and Hall et al. (1971) described a high incidence of duodenal ulceration in patients with coronary heart disease and peripheral vascular disease respectively. Sloan et al. (1970) described a pattern of impaired glucose tolerance and hyperinsulinaemia in patients with peripheral atherosclerosis, whish is similar to the results which we have obtained in patients with duodenal ulcer before operation. An increased insulin response to oral glucose has also been described in patients surviving myocardial infarction (Peters and Hales, 1965). Stout (1968) has shown in experimental animals that insulin stimulates both lipogenesis and cholesterol synthesis in arterial tissue. There are many possible reasons why duodenal ulcer disease and vascular disease may be related. The present results suggest that abnormal carbohydrate metabolism may be common to both.

\section{References}

Abrams, M. E., Jarrett, R. J., Keen, H., Boyns, D. R., and Crossley, J. N. (1969). British Medical Fournal, 1, 599.

Abrahamson, E. M. (1945). American fournal of Digestive Diseases, 12, 379. Allan, T. M., and Dawson, A. A. (1968). British Heart fournal, 30, 377 Bagdade, J. D., Bierman, E. L., and Porte, D. (1967). Fournal of Clinical Investigation, 46, 1549.

Berger, S., Downey, J. L., Traisman, H. S., and Metz, R. (1966). New England Fournal of Medicine, 274, 1460 .

Berkowitz, D. (1969). American fournal of Digestive Diseases, 14, 691.

Boyns, D. R., Jarrett, R. J., and Keen, H. (1966). Lancet, 1, 409. British Medical fournal, 1971, 1, 129.

Buchanan, K. D., McKiddie, M. T., Lindsay, A. C., and Manderson, W. G. (1967). Gut, 8, 325.

Burns, T. W., Bregant, R., van Peenan, H. J., and Hood, T. E. (1965). fournal of Laboratory and Clinical Medicine, 65, 927.

Cameron, A. J., Ellis, J. P., McGill, J. I., and Le Quesne, L. P. (1969). Gut, 10,825 .
Chisholm, D. J., Young, J. D., and Lazarus, L. (1969). fournal of Clinical Investigation, 48, 1453.

Dupre, J. (1964). Fournal of Physiology, 175, 58.

Dupre, J., Curtis, J. D., Unger, R. H., Waddell, R. W., and Beck, J. C. (1969). Fournal of Clinical Investigation, 48, 745.

Evensen, O. K. (1942). Acta Medica Scandinavica, Suppl. No. 126.

Fitzgerald, M. G., and Keen, H. (1964). Lancet, 1, 1325.

Griffith, G. H., Owen, G. M., Cambell, H., and Shields, R. (1968). Gastroenterology, 54, 1.

Hales, C. N., and Randle, P. J. (1963). Biochemical fournal, 88, 137.

Hall, W. H.' (1971). American Fournal of Digestive Diseases, 16, 139.
Hall, R., Bunch, G. A., and Humphrey, C. S. (1971). British Medical fournal, 3, 767.

Hobsley, M., and Le Quesne, L. P. (1960). British Medical fournal, 1, 147. Holdsworth, C. D., Turner, D., and McIntyre, N. (1969). British Medical fournal, 4, 257.

Jones, A. W., Kirk, R. S., and Bloor, K. (1970). Gut, 11, 679.

Kaess, H., Schlierf, G., and von Mikulicz-Radecki, J. G. (1970). Metabolism, $19,214$.

McIntyre, N., Holdsworth, C. D., and Turner, D. S. (1964). Lancet, 2, 20. McIntyre, N., Holdsworth, C. D., and Turner, D. S. (1965). Fournal of Clinical Endocrinology and Metabolism, 25, 1317.

Morley, G., Dewson, A., and Marks, V. (1968). Proceedings of the Association of Chemical Biochemists, 5, 43.

Oakley, N. W., et al. (1970). Clinical Science, 39, 663.

Ohgawara, H., Mizuno, Y., Tasaka, Y., and Kosaka, K. (1969). fournal of Clinical Endocrinology and Metabolism, 29, 1261.

Okada, S., Juramochi, K., Tsukahara, T., and Ooinoue, T. (1930). Archives of Internal Medicine, 45, 783.

Perley, M., and Kipnis, D. M. (1965). Fournal of Laboratory and Clinical Medicine, 66, 1009.

Perreau, P., Joubaud, F., Benbouali, A., Pithon, G., and Verger, P. (1969). Acta Gastro-Enterologica Belgica, 32, 80.

Peters, N. and Hales, C. N. (1965). Lancet, $1,1144$.

Platt, W. D., Dotti, L. B., and Beckman, R. S. (1949). Gastroenterology, 13, 20.

Rehfeld, J. F., and Heding, L. G. (1970). British Medical fournal, 1, 706. Roholm, K. (1930). Acta Medica Scandinavica, 73, 472.

Samols, E., Tyler, J., Marri, G., and Marks, V. (1965). Lancet, 2, 1257. Sloan, J. M., MacKay, J. S., and Sheridan, B. (1970). British Medical fournal, 4, 586 .

Spearman, C. (1904). American fournal of Psychology, 15, 88.

Stout, R. W. (1968). Lancet, 2, 702.

Sullivan, M. B., and Boshell, B. R. (1964). British Medical fournal, 1, 414. Unger, R. H., and Eisentraut, A. M. (1964). Diabetes, 13, 563.

Unger, R. H., Ketterer, H., Dupre, J., and Eisentraut, A. M. (1967). Fournal of Clinical Investigation, 46, 630.

Yalow, R. S., Glick, S. M., Roth, J., and Berson, S. A. (1965). Annals of the New York Academy of Sciences, 131, 357.

Young, J. D., Lazarus, L., and Chisholm, D. J. (1968). Lancet, 2, 914.

\title{
Hypertension and Hyperparathyroidism
}

\author{
F. D. ROSENTHAL, S. ROY
}

British Medical fournal, 1972, 4, 396-397

\section{Summary}

Of 40 patients with primary hyperparathyroidism 13 were hypertensive. Nine presented with hypertension and, of these, seven were discovered to have hyperparathyroidism by the routine determination of serum calcium in 900 patients referred for investigation of hypertension. The association of hypertension and hyperparathyroidism is well recognized but the cause is in doubt. The incidence of primary hyperparathyroidism in patients with hypertension is about 1 in 130 , which is considerably higher than in the general population (1 in 1,000-2,000). All patients with hypertension should have a routine serum calcium estimation. Parathyroidectomy in these otherwise asymptomatic cases may prevent renal damage.

\section{Introduction}

The clinical manifestations of hyperparathyroidism are many, and patients may present with urinary calculi, renal calcification,

Department of Medicine, Leicester Royal Infirmary, Leicester F. D. ROSENTHAL, M.D., F.R.C.P., Consultant Physician S. ROY, M.B., M.R.C.P., Senior Registrar

skeletal symptoms, or manifestations of hypercalcaemia. Occasionally on routine screening a raised serum calcium may lead to the diagnosis in patients apparently free from symptoms (Dent, 1962; Gough et al., 1971). Hypertension in hyperparathyroidism was described by Hellstrom et al. (1958). In their series of 95 patients $47(49 \%)$ had a diastolic blood pressure of $100 \mathrm{~mm} \mathrm{Hg}$ or above. George et al. (1965) found the incidence to be $20 \%$, and Pyrah et al. (1966) between 30 and 50\%.

\section{Patients and Investigations}

During the period $1960-71,40$ patients with primary hyperparathyroidism were diagnosed in Leicester. Thirty-one presented with renal stones, renal colic, or symptoms of hypercalcaemia. Four patients had diastolic blood pressure of above $110 \mathrm{~mm} \mathrm{Hg}$. All had fasting serum calcium levels of $10.4 \mathrm{mg} /$ $100 \mathrm{ml}$ or above (normal range 8.8 to $10.3 \mathrm{mg} / 100 \mathrm{ml}$.) The diagnosis was confirmed by the removal of a parathyroid adenoma in all patients except one who had parathyroid hyperplasia. In all cases the serum calcium returned to normal after operation.

In the period 1968-71 the serum calcium was measured in 900 patients presenting with diastolic hypertension of at least $110 \mathrm{~mm} \mathrm{Hg}$. Raised serum calcium levels were found in seven, none of whom had the clinical features suggestive of hyperparathyroidism or renal stones. In addition there were two 
hypertensive patients before 1968 in whom a raised serum calcium was found. One of these was shown to have a renal stone, the other gave a history of renal colic. In all these patients the removal of a parathyroid adenoma resulted in the return of the serum calcium to normal. It is of interest that of these 900 patients with diastolic hypertension none had Cushing's syndrome or a phaeochromocytoma, but one had coarctation of the aorta.

Of the total of 13 hypertensive patients renal function was found to be impaired in two, one of whom had renal stones, and the other had proteinuria. The other patients had a normal blood urea and a creatinine clearance greater than $80 \mathrm{ml} / \mathrm{min}$. Renal infection was present in two patients with calculi but in these the creatinine clearance was normal. Hypercalciuria - that is, a 24-hour urine calcium above $300 \mathrm{mg}$-was present in 11 patients and absent in two (one with renal insufficiency and one asymptomatic patient). There was no significant drop in the blood pressure after parathyroidectomy in any patient and no change in hypertensive therapy was possible. Two of the seven asymptomatic patients with hypertension had renal biopsies. Only minor vascular hypertensive changes were seen, and there was no excess calcium deposition.

The details of the 13 hypertensive patients are shown in Tables I and II.

\section{Discussion}

In this series the incidence of diastolic hypertension in patients with hyperparathyroidism who have renal stones or symptoms of hypercalcaemia is $20 \%$. In the cases presenting with hypertension the incidence of hyperparathyroidism is about 1 in 130. The results of screening surveys (Haff et al., 1970; Boonstra and Jackson, 1971) suggest that the incidence of primary hyperparathyroidism in the population is between 1 in 1,000 and 1 in 2,000. Our results indicate that the association of hyperparathyroidism and hypertension is not fortuitous.

Of great clinical importance is the problem of whether hypertension results from renal damage. There is no doubt that prolonged hypercalcaemia can damage the kidney. It has been claimed by Britten et al. (1971) that parathyroidectomy does not prevent deterioration of renal function. Many of the cases, however, were advanced by the time of surgery. Hellstrom et al. (1958) claimed that hypertension could be related to renal damage. Many of their cases were also advanced yet frank nephrocalcinosis did not correlate with hypertension. The hypertension in $20 \%$ of their patients remitted after para- thyroidectomy, a finding difficult to explain if the hypertension was due to renal damage.

The degree of hyperparathyroidism found by screening hypertensive patients has been mild, and unassociated with clinical symptoms. Impaired renal function was present in only two of our 13 hypertensive subjects. Renal biopsy in two patients without stones showed only minor vascular changes. It is not clear whether parathyroidectomy is necessary in asymptomatic patients with hypertension and normal renal function, but in the present state of knowledge operation seems indicated. The present patients were not observed for a longer period than that required to establish a firm diagnosis. No change in blood pressure was found after operation. Our findings suggest that hypertension in hyperparathyroidism is often not associated with severe renal functional impairment.

Essential hypertension is often associated with a raised serum cholesterol (Hall, 1965) and uric acid (Cannon et al., 1966). Primary hyperparathyroidism may be another of these associations but it is of interest that in this condition, too, there is an unexplained rise in serum uric acid (Scott et al., 1964). It could be that some common metabolic pathway is involved.

Our findings show that routine screening of hypertensive patients will disclose a small proportion of patients with hyperparathyroidism before bone disease, urinary tract abnormalities, or symptoms of hypercalcaemia are evident.

We wish to thank our colleagues in the Leicester Group of Hospitals for allowing us access to their case material, and Dr. V. W. Pugh for carrying out the calcium estimations. We also thank Professor D. S. Munro for his help in reviewing the manuscript.

\section{References}

Boonstra, C. E., and Jackson, C. E. (1971). Fournal of Clinical Pathology,

B5, 523 . (1971), Lancet, 2, 74.

Cannon, P. G., Statham, W. B., Demartini, F. E., Somers, S. C., and Laragh, J.' H. (1966). New England Fournal of Medicine, 275, 457.

Dent, C. E. (1962). British Medical fournal, 2, 1419, 1495.

George, J. M., Rabson, A., Ketcham, A., and Bartter, F. C. (1965). Quarterly Journal of Medicine, 34, 291.

Gough, M. H., Smith, R., and Bishop, M. C. (1971). Lancet, 1, 1178.

Haff, R. C., Black, W. C., and Ballinger, W. F. (1970). 171, 85.

Hall, A. T.' (1965). Arthritis and Rheumatism, 8, 846.

Hellstrom, J., Birke, G., and Edvall, C. A. (1958). British fournal of Urology, 30, 13 .

Pyrah, L. H., Hodgkinson, A., and Anderson, C. K. (1966). British fournal of Surgery, 53, 245.

Scott, J. T., Dixon, A. St. J., and Bywaters, E. G. L. (1964). British Midical Fournal, $1,1070$.

TABLE I-Patients with Hypertension and Primary Hyperparathyroidism with no Renal Stones or Infection

\begin{tabular}{|c|c|c|c|c|c|c|c|c|c|c|c|}
\hline \multirow{2}{*}{$\begin{array}{l}\text { Case } \\
\text { No. }\end{array}$} & \multirow{2}{*}{$\begin{array}{c}\text { Sex and } \\
\text { Age }\end{array}$} & \multirow{2}{*}{$\begin{array}{c}\text { Blood } \\
\text { Pressure } \\
(\mathrm{mm} \text { Hg) }\end{array}$} & \multirow{2}{*}{$\begin{array}{l}\text { Renal } \\
\text { Stones }\end{array}$} & \multirow{2}{*}{$\begin{array}{l}\text { Renal } \\
\text { Colic }\end{array}$} & \multirow{2}{*}{$\begin{array}{c}\text { Renal } \\
\text { Infection }\end{array}$} & \multirow{2}{*}{$\begin{array}{c}\text { Renal } \\
\text { Function }\end{array}$} & \multirow{2}{*}{$\begin{array}{c}\text { 24-hour } \\
\text { Urine } \\
\text { Proteins } \\
\text { (g/l.) }\end{array}$} & \multirow{2}{*}{$\begin{array}{l}\text { 24-hour } \\
\text { Urine } \\
\text { Calcium } \\
\text { (mg/24 hr) }\end{array}$} & $\begin{array}{l}\text { Serum } \\
\text { Calcium }\end{array}$ & $\begin{array}{c}\text { Serum } \\
\text { Phosphate }\end{array}$ & \multirow{2}{*}{$\begin{array}{c}\text { Serum Alkaline } \\
\text { Phosphatase }\end{array}$} \\
\hline & & & & & & & & & \multicolumn{2}{|c|}{$(\mathrm{mg} / 100 \mathrm{ml})$} & \\
\hline $\begin{array}{l}1 \\
2 \\
3 \\
4 \\
5 \\
6 \\
7\end{array}$ & $\begin{array}{l}\text { F. } \mathbf{6 8} \\
\text { M. } 52 \\
\text { F. } 57 \\
\text { M. } 45 \\
\text { F. } 55 \\
\text { F. } 60 \\
\text { M. } 50\end{array}$ & $\begin{array}{l}200 / 120 \\
240 / 130 \\
240 / 120 \\
200 / 120 \\
180 / 130 \\
190 / 120 \\
180 / 120\end{array}$ & $\begin{array}{l}= \\
\bar{z} \\
\bar{z}\end{array}$ & $\begin{array}{l}= \\
z \\
z\end{array}$ & $\begin{array}{l}= \\
\bar{z} \\
\bar{z}\end{array}$ & $\begin{array}{l}\text { Impaired } \\
\text { Normal } \\
\text { Normal } \\
\text { Normal } \\
\text { Normal } \\
\text { Normal } \\
\text { Normal }\end{array}$ & $\begin{array}{l}1.6 \\
= \\
=\end{array}$ & $\begin{array}{l}250 \\
400 \\
500 \\
250 \\
400 \\
450 \\
350\end{array}$ & $\begin{array}{l}11.4 \\
11.1 \\
11.5 \\
11.4 \\
11.2 \\
11.1 \\
11.0\end{array}$ & $\begin{array}{l}3.5 \\
2.5 \\
3.0 \\
2.5 \\
2.6 \\
2.7 \\
3.0\end{array}$ & $\begin{array}{l}\text { Normal } \\
\text { Normal } \\
\text { Normal } \\
\text { Normal } \\
\text { Normal } \\
\text { Normal } \\
\text { Normal }\end{array}$ \\
\hline
\end{tabular}

TABLE II-Patients with Hypertension and Primary Hyperparathyroidism with Renal Stones and/or Infe ction

\begin{tabular}{|c|c|c|c|c|c|c|c|c|c|c|c|}
\hline \multirow{2}{*}{$\begin{array}{l}\text { Case } \\
\text { No. }\end{array}$} & \multirow{2}{*}{$\begin{array}{c}\text { Sex and } \\
\text { Age }\end{array}$} & \multirow{2}{*}{$\begin{array}{c}\text { Blood } \\
\text { Pressure } \\
(\mathrm{mm} \mathrm{Hg})\end{array}$} & \multirow{2}{*}{$\begin{array}{l}\text { Renal } \\
\text { Stones }\end{array}$} & \multirow{2}{*}{$\begin{array}{l}\text { Renal } \\
\text { Colic }\end{array}$} & \multirow{2}{*}{$\begin{array}{c}\text { Renal } \\
\text { Infection }\end{array}$} & \multirow{2}{*}{$\begin{array}{c}\text { Renal } \\
\text { Function }\end{array}$} & \multirow{2}{*}{$\begin{array}{c}\text { 24-hour } \\
\text { Urine } \\
\text { Proteins } \\
\text { (g/l.) }\end{array}$} & \multirow{2}{*}{$\begin{array}{l}\text { 24-hour } \\
\text { Urine } \\
\text { Calcium } \\
\text { (mg/24 hr) }\end{array}$} & $\begin{array}{l}\text { Serum } \\
\text { Calcium }\end{array}$ & $\begin{array}{c}\text { Serum } \\
\text { Phosphate }\end{array}$ & \multirow{2}{*}{$\begin{array}{l}\text { Serum Alkaline } \\
\text { Phosphatase }\end{array}$} \\
\hline & & & & & & & & & \multicolumn{2}{|c|}{$(\mathrm{mg} / 100 \mathrm{ml})$} & \\
\hline $\begin{array}{l}1 \\
2 \\
3 \\
4 \\
5 \\
6\end{array}$ & $\begin{array}{l}\text { F. } 64 \\
\text { M. } 45 \\
\text { F. } 67 \\
\text { M. } 53 \\
\text { F. } 45 \\
\text { M. } 57\end{array}$ & $\begin{array}{l}180 / 140 \\
220 / 140 \\
200 / 110 \\
190 / 130 \\
190 / 120 \\
170 / 110\end{array}$ & $\begin{array}{l}++ \\
+ \\
+ \\
+ \\
++ \\
++\end{array}$ & $\begin{array}{l}+ \\
+ \\
+ \\
+ \\
+ \\
+\end{array}$ & $\frac{ \pm}{ \pm}$ & $\begin{array}{l}\text { Normal } \\
\text { Normal } \\
\text { Impaired } \\
\text { Normal } \\
\text { Normal } \\
\text { Normal }\end{array}$ & $\begin{array}{l}\overline{0.2} \\
0.2 \\
= \\
=\end{array}$ & $\begin{array}{l}450 \\
500 \\
400 \\
600 \\
400 \\
550\end{array}$ & $\begin{array}{l}11 \cdot 8 \\
12 \cdot 3 \\
13 \cdot 4 \\
12 \cdot 00 \\
11 \cdot 0 \\
12 \cdot 0\end{array}$ & $\begin{array}{l}2.9 \\
2.9 \\
2.5 \\
3.0 \\
2.5 \\
2.0\end{array}$ & $\begin{array}{l}\text { Normal } \\
\text { Normal } \\
\text { Normal } \\
\text { Normal } \\
\text { Normal } \\
\text { Normal }\end{array}$ \\
\hline
\end{tabular}

Urine and serum calcium levels were an average of six readings.

Normal range of serum calcium $=8 \cdot 8-10 \cdot 3 \mathrm{mg} / 100 \mathrm{ml}$.
There was no radiological evidence of bone disease in any patient. 